\title{
Somatotype Profile and Body Composition of Players from the Mexican Professional Basketball League
}

\author{
Perfil Somatotípico y Composición Corporal de Jugadores \\ de la Liga Mexicana de Básquetbol Profesional
}

\author{
Paulina Yesica Ochoa Martínez*; Javier Arturo Hall López*; Edgar Ismael Alarcón Meza*; \\ Emilio Manuel Arráyales Millán* \& Ricardo Sánchez León*
}

OCHOA, M. P. Y.; HALL, L. J. A.; ALARCÓN, M. E. I.; ARRÁYALES, M. E. M. \& SÁNCHEZ, L. R. Somatotype profile and body composition of players from the Mexican professional basketball league. Int. J. Morphol., 32(3):1032-1035, 2014.

SUMMARY: The purpose of this research was to determine the somatotype profile and body composition of team members of Soles de Mexicali from the Mexican professional basketball league season 2012. A descriptive cross-sectional study in which 10 members of that team are evaluated to determine the somatotype and body composition, they were assessed with anthropometric variables in accordance with ISAK (International Society for the Advancement of Kinanthropometry was performed) the equipment used was the Tom Kit Rosscraft Inc. The somatotype and body composition were determined through measurements of body weight (cm), height (cm), eight skinfolds ( $\mathrm{mm}$ ) triceps, sub scapular, biceps, iliac crest, supra spinal, abdominal, front thigh, medial calf, eleven circumferences $(\mathrm{cm})$ arm relaxed, flexed arm, forearm, wrist, chest, low waist, high hip, thigh, buttock $1 \mathrm{~cm}$, mid-thigh, calf and ankle, and two bone diameters $(\mathrm{cm})$ humeral and femur. The data were processed or through Life Size Software Sports Scientific Reynolds. The following data are reported in the first reference of the Mexican league players assessed a somatotype 2.94-6.35-2.06 average and the percentage of body fat of the subjects tested was $14.46 \%$. The values found in this study indicate a significant an optimal state of body fat percentage and somatotype similar when is compared with existing studies on national teams and international basketball.

KEY WORDS: Basketball; Somatotype; Body Composition.

\section{INTRODUCTION}

The kinanthropometry has been defined as the quantitative interface of the anatomy and physiology or between human structure and function (Norton \& Olds, 1996); the human body is composed of a variety of different tissue types including lean tissues muscle, bone, and organs that are metabolically active, and fat adipose tissue that is not (Rexhepi \& Brestovci, 2010, 2012). Somatotype is defined as a method that describes an individual current body shape and composition, expressed in the quantification of three components (endomorphy, which express body fat content, mesomorphy is the development of skeletal muscle and ectomorphy is the linearity or thinness of the body) relative to height (Carter \& Heath, 1990); The assessment of somatotype in the field of sports has been associated with the level of fitness and performance, the classification of balanced mesomorph somatotype is characterized by dominance in the mesomophy component and the tendency on basketball players (Popovic et al., 2013).
The basketball requires specific morphological characteristics; studies support than team athletes show great homogeneity with very specific anthropometric patterns and closely related to player performance in competition (Toriola et al., 1985), in sports sciences is important to improve the efficiency and quality of evaluations applied to athletes since its formation in the smaller categories as for the training of competitive teams (Pelin et al., 2009), at present there are no specific references somatotype and body composition in Mexican basketball players; Kinanthropometry has been used as a tool in the study of physical activity and sport to determine and evaluates the body characteristics according to the size, shape, proportion, body composition, maturation and function, it is considered as a fundamental discipline for detection and troubleshooting related to physical growth, exercise, nutrition and sports physical performance context (Marfell-Jones et al., 2006), the interest in understanding about the anthropometric characteristics of professional bas- 
ketball players has led to conduct this research, in order to describe the sample in question and thereby give us a better idea about the requirements of body composition and somatotype for better training according to their position on the court and their anthropometric characteristics, this in order to know which aspects should be observed in the detection of potential sports talents (Ziv \& Lidor, 2009).

\section{MATERIAL AND METHOD}

The study design was descriptive cross-sectional, with non-probabilistic and convenience sampling, there where 10 subjects members of professional basketball team participants Soles de Mexicali in the Mexican Basketball League 2012 season with an average age of $24.8 \pm 2.1$ years, who voluntarily agreed to participate. Anthropometric measurements were obtained at the Laboratory of Human Motricity Biosciences at the School of Sports of the Autonomous University of Baja California.

Table I. Mean, standard deviation and range of general anthropometric characteristics of basketball players $(\mathrm{n}=18)$.

\begin{tabular}{lcc}
\hline Basics & $\boldsymbol{X}$ & $\boldsymbol{D S}$ \\
\hline Body weight mass $(\mathrm{kg})$ & 100.21 & 17.92 \\
Height $(\mathrm{cm})$ & 193.27 & 10.24 \\
Skinfolds $(\boldsymbol{m m})$ & & \\
Ttriceps & 9.35 & 4.97 \\
Biceps & 4.40 & 1.37 \\
Sub scapular & 11.90 & 3.96 \\
Supra spinal & 12.25 & 5.26 \\
Iliac crest & 15.65 & 8.59 \\
Abdominal & 17.60 & 7.54 \\
Front thigh & 12.75 & 4.87 \\
Medial calf & 8.25 & 4.87 \\
Circumferences $(\mathbf{c m})$ & & \\
Arm relaxed & 36.31 & 2.80 \\
Flexed arm & 38.61 & 3.08 \\
Fore arm & 31.02 & 2.65 \\
Wrist & 19.28 & 1.77 \\
Chest & 107.63 & 8.76 \\
Waist & 88.65 & 6.49 \\
Hip & 107.11 & 7.61 \\
Thigh gluteal 1 cm & 66.72 & 5.87 \\
Mid-thigh & 62.73 & 4.83 \\
Maximum calf & 42.73 & 4.89 \\
Ankle & 25.53 & 2.52 \\
Bone diameters $(\boldsymbol{c m})$ & & \\
Humeral & 7.92 & 0.47 \\
Femur & 10.88 & 0.71 \\
\hline
\end{tabular}

To determine the somatotype the Heath \& Carter method was used; body composition was calculated by the LifeSize for body composition analysis Human Kinetics Software; Anthropometric measurements were conducted by a level two anthropometrist following the guidelines set by the International Society for Advancement of Kinanthropometry (ISAK) with a technical error of measurement less or equal to $1 \%$. The following measurements were taken: body weight $(\mathrm{cm})$, height $(\mathrm{cm})$, eight skinfolds (mm) triceps, sub scapular, biceps, iliac crest, supra spinal, abdominal, front thigh, medial calf, eleven circumferences $(\mathrm{cm})$ arm relaxed, flexed arm, forearm, wrist, chest, low waist, high hip, thigh, buttock $1 \mathrm{~cm}$, mid-thigh, calf and ankle, and two bone diameters $(\mathrm{cm})$ humeral and femur. The equipment used was a Seca 220 scale and stadiometer, and the Rosscraft Inc., Tomkit (Slim guide skinfold caliper, bone diameter vernier and Lufkin metal anthropometric tape).

\section{RESULTS}

The values of the variables are shown in mean and standard deviation; Table I shows the general and anthropometric characteristics, and somatotype components and body composition percentage are referred in Table II; The spatial distribution of somatotype and dispersion (SDD) and attitudinal distances (SAD) of basketball players respect to their average value and game position can be seen in Figures 1 and 2 .

Table II. Mean and standard deviation of somatotype components and body composition Percentage of basketball players.

\begin{tabular}{lcc}
\hline Somatotype components & X & DS \\
\hline Endomorphy & 2.94 & 1.07 \\
Mesomorphy & 6.35 & 1.14 \\
Ectomorphy & 2.06 & 0.96 \\
SDD (somatotype dispersion distance) & 6.68 & 2.81 \\
SAD (somatotype attitudinal distance) & 3.68 & 1.18 \\
X Coordinate & 0.88 & 1.89 \\
Y Coordinate & 7.69 & 2.45 \\
\hline Body Composition & Percentage $(\boldsymbol{\%})$ \\
\hline Fat Mass & \multicolumn{2}{c}{14.64} \\
Muscle Mass & \multicolumn{2}{c}{48.59} \\
Bone Mass & \multicolumn{2}{c}{17.56} \\
Residual Mass & \multicolumn{2}{c}{19.19} \\
\hline
\end{tabular}



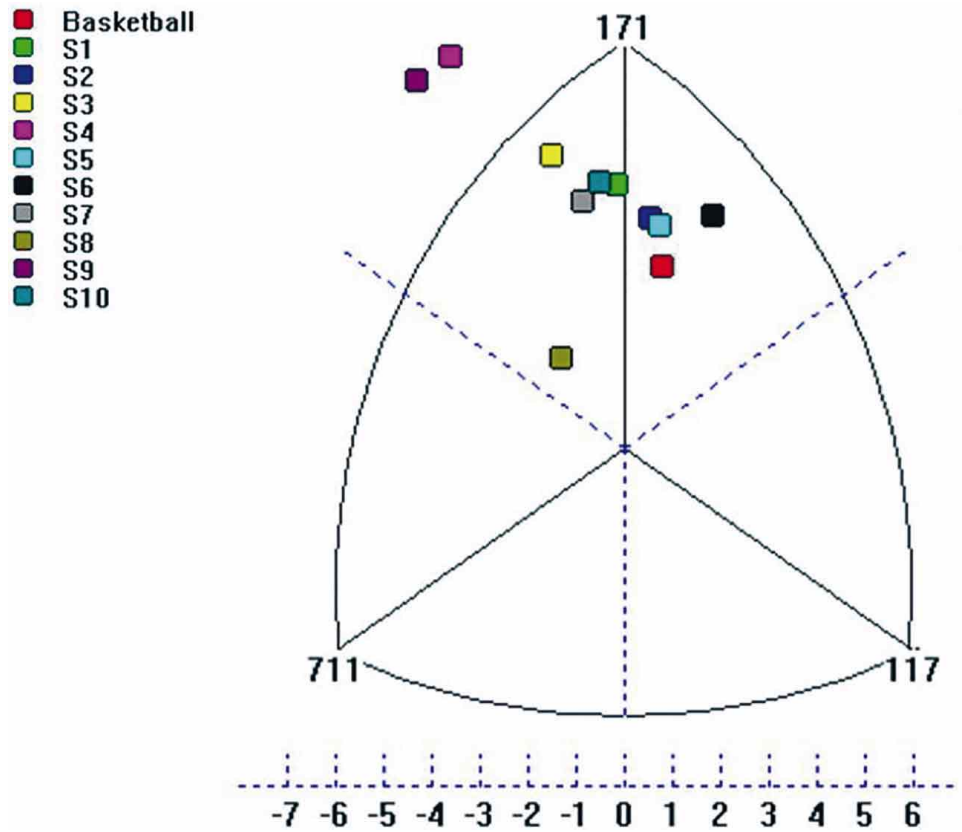

Fig. 1. Spatial distribution of somatotype of basketball players.

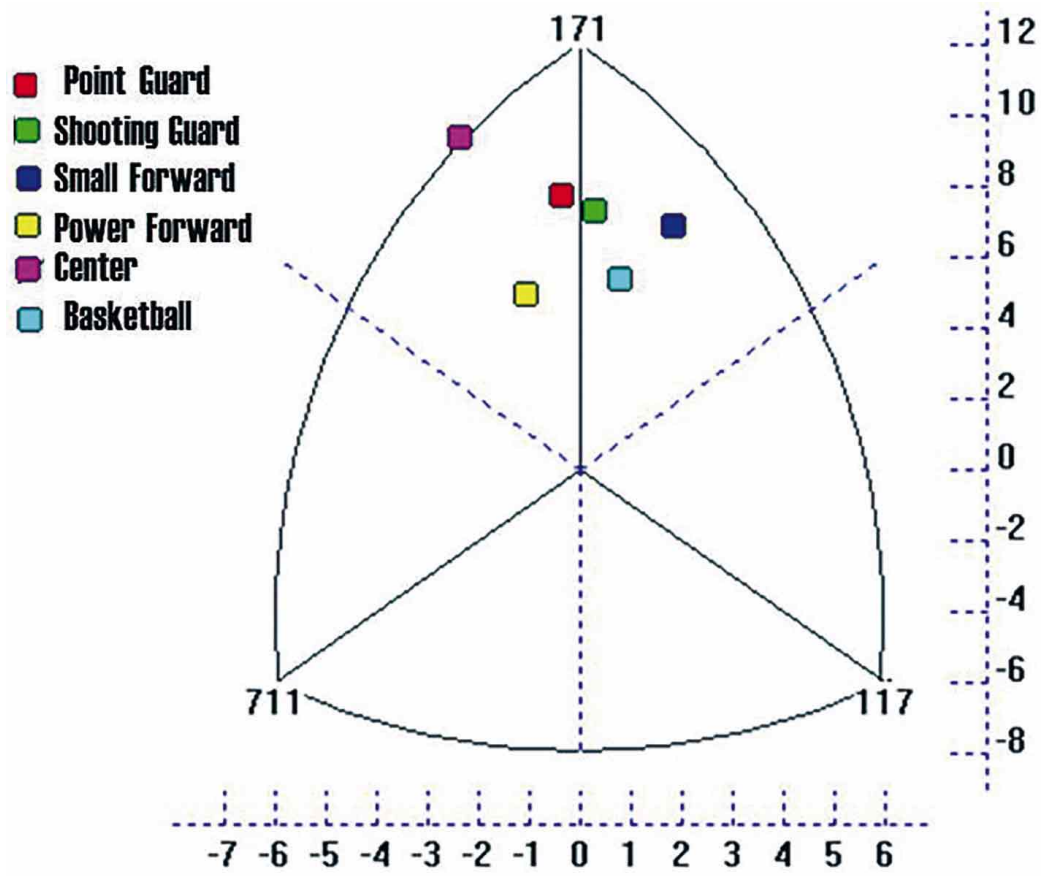

Fig. 2. Spatial distribution of somatotype of basketball players for game position.

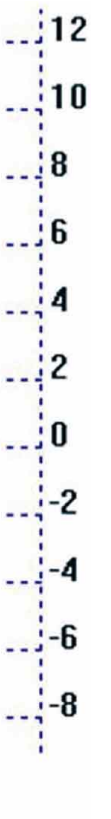

\section{DISCUSSION}

In recent decades, basketball has evolved in its rules and tactical game systems which has directly influenced by the physical demands and structural and functional characteristics of the players (Ziv et al.), according to these more knowledge related to energy demands, morph functional and biomechanical profile of the players in this sport is required in order to improve the intensity of the loads training to get better performance thus relevant information is obtained from the kineantropometry (Ostojic et al., 2006), furthermore the important for selection of players by specific position (Ben Abdelkrim et al., 2010). Studies conducted on basketball players report somatotypes with predominantly mesomorphy (muscle mass) and ectomorphy (thinness or linearity) over the endomorph (fat mass) (Toriola et al.; Mathur et al., 1985; Viviani, 1994; Pelin et al.) the studies were performed in amateur basketball players and the reference data since previous two decades, as this study focuses on identifying anthropometric characteristics and body composition of elite basketball players from club Soles de Mexicali, season 2012. The average percentage of body fat in subjects studied was $14.64 \%$ higher than research conducted in Australian elite ballers $8.4 \%$ (Leicht, 2007), using the same methodology to determine the percentage of fat, when comparing the values are the subjects studied have more value of body fat component, the found values show the subjects evaluated as falling within the standard recommended in relation to the general population. The somatotype is a useful unit of measure in epidemiological studies that highlight the overall health status of the people through anthropometric characteristics, but is more useful in physical evaluation of athletes (Garrido-Chamorro et al., 2012), recommended by the trend muscles of athletes, even though when comparing the average of soles of Mexicali team with reference of basketball players. The values found in this study indicate a significant an optimal state of body fat percentage and similarity when compared with existing studies in man basketball teams belonging to national and international. 
OCHOA, M. P. Y.; HALL, L. J. A.; ALARCóN, M. E. I.; ARRÁYALES, M. E. M. \& SÁNCHEZ, L. R. Perfil somatotípico y composición corporal de jugadores de la Liga Mexicana de Básquetbol Profesional. Int. J. Morphol., 32(3):1032-1035, 2014.

RESUMEN: El propósito fue determinar el somatotipo y composición corporal de los integrantes del equipo de basketball Soles de Mexicali temporada 2012. Se realizó un estudio transversal descriptivo en el que se evaluó a los 10 integrantes, para determinar el porcentaje de grasa corporal se utilizó el método antropométrico de acuerdo con las técnicas establecidas por la ISAK (Sociedad Internacional para el Avance de la Kineantropometría). El equipo utilizado fue el Tom Kit de Rosscraft Inc. Recomendado por la ISAK para la aplicación de mediciones y que consta de calibrador de pliegues cutáneos Slim Guide, vernier de diámetros óseos, cinta métrica metálica tipo Lufkin, además de estadímetro y bascula. Se tomaron las siguientes mediciones masa corporal: estatura, 8 panículos adiposos (tríceps, subescapular, bíceps, iliocrestal, supraespinal, abdominal, muslo frontal, pierna medial), 11 circunferencias (brazo relajado, brazo flexionado, antebrazo, muñeca, tórax, cintura mínima, cadera máxima, muslo a $1 \mathrm{~cm}$ del glúteo, muslo medio, pantorrilla y tobillo) y 2 diámetros óseos (húmero y fémur). Los datos o fueron procesados por medio del software LifeSize de Nolds Sports Scientific determinando el porcentaje de grasa corporal. Los datos obtenidos son la primer referencia reportada en basquetbolistas de la liga mexicana determinados un somatotipo promedio de 2,94-6,35-2,06 y el porcentaje de grasa corporal promedio fue de $14.46 \%$. Los valores encontrados en el presente estudio indican un considerable estado óptimo de porcentaje de grasa y similitud al compararlos con estudios existentes a equipos de basketball nacional e internacional.

\section{PALABRAS CLAVE: Basketball; Somatotipo; Composición Corporal.}

\section{REFERENCES}

Ben Abdelkrim, N.; Chaouachi, A.; Chamari, K.; Chtara, M. \& Castagna, C. Positional role and competitive-level differences in elite-level men's basketball players. J. Strength Cond. Res., 24(5):1346-55, 2010

Carter, J. E. L. \& Heath, B. H. Somatotyping - Development and Applications. Cambridge, Cambridge University Press, 1990.

Leicht, A. S. Aerobic power and anthropometric characteristics of elite basketball referees. J. Sports Med. Phys. Fitness, 47(1):4650, 2007.

Garrido-Chamorro, R.; Sirvent-Belando, J. E.; González-Lorenzo, M.; Blasco-Lafarga, C. \& Roche, E. Skinfold sum: reference values for top athletes. Int. J. Morphol., 30(3):803-9, 2012.

Marfell-Jones, M.; Olds, T.; Stewart, A. \& Carter, L. International standards for anthropometric assessment. Potchefstroom, ISAK, 2006.

Mathur, D. N.; Toriola, A. L. \& Igbokwe, N. U. Somatotypes of Nigerian athletes of several sports. Br. J. Sports Med., 19(4):219-20, 1985.

Norton, K. \& Olds, T. Antropometrica. Marrickville. Sidney, Southwood Press, 1996.

Ostojic, S. M.; Mazic, S. \& Dikic, N. Profiling in basketball: physical and physiological characteristics of elite players. $J$. Strength Cond. Res., 20(4):740-4, 2006.

Pelin, C.; Kürkcüoglu, A.; Ozener, B.; Yazici, A. C. Anthropometric characteristics of young Turkish male athletes. Coll. Antropol., 33(4):1057-63, 2009.
Popovic, S.; Akpinar, S.; Jaksic, D.; Matic, R. \& Bjelica, D. Comparative Study of Anthropometric Measurement and Body Composition between Elite Soccer and Basketball Players. Int. J. Morphol., 31(2):461-7, 2013.

Rexhepi, A. M. \& Brestovci, B. The differences in body volume and skinfold thickness between basketball players and footballers. Int. J. Morphol., 28(4):1069-74, 2010.

Rexhepi, A. M.; Brestovci, B. \& Mucolli, A. Prediction of explosive power of basketball players based on their morpho-functional characteristics. Int. J. Morphol., 30(2):719-22, 2012.

Toriola, A. L.; Salokun, S. O. \& Mathur, D. N. Somatotype characteristics of male sprinters, basketball, soccer, and field hockey players. Int. J. Sports Med., 6(6):344-6, 1985.

Viviani, F. The somatotype of medium class Italian basketball players. J. Sports Med. Phys. Fitness, 34(1):70-5, 1994.

Ziv, G, \& Lidor, R. Physical attributes, physiological characteristics, on-court performances and nutritional strategies of female and male basketball players. Sports Med., 39(7):547-68, 2009.

Correspondence to:

Javier Arturo Hall López

Faculty of Sports

Autonomous University of Baja California (UABC)

Baja California

MÉXICO

Email: javier@uabc.edu.mx

Received: $31-02-2014$

Accepted: 28-03-2014 